\title{
The association of Helicobacter pylori in the Pathogenesis of Hyperemesis Gravidarum
}

\author{
${ }^{1}$ Basima Sh. Al Ghazali, ${ }^{2}$ Jackleen Ali Hussein \\ ${ }^{I}$ Department of Obstetrics and Gynecology, Faculty of Medicine, Kufa University, consultant Obstetrician and \\ Gynecologist in Al- Zahraa Teaching Hospital, Najaf, Iraq, \\ ${ }^{2}$ Obstetrician and Gynecologist, ${ }^{A l}$ - Najaf health office, Najaf, Iraq
}

\begin{abstract}
Background: Nausea and vomiting during pregnancy has a pervasive detrimental impact on women's family, social and professional life and hyperemesis gravidarum $(H G)$ is the most severe form of this disorder.
\end{abstract}

The Purpose:

To evaluate the association of Helicobacter pylori infection in the pathogenesis of hyperemesis gravidarum $(H G)$.

Methods:

Fourty five pregnant women with hyperemesis gravidarum were recruited from out- patient clinics \& emergency department of Al-Zahra' Teaching Hospital for Gynaecology\& Obstetrics / Kufa University. Fourty five normal pregnant women were used as a control group. Serum testing for H-pylori IgG antibody titre using (ELISA) method was done for both the patient group and the control group.

Results:

Thirty eight Patients of the forty five hyperemesis gravidarum group (84.44\%) were H. pylori positive and twenty one of the forty five control group (46.7\%) were H.pylori positive.

\section{Conclusion:}

Helicobacter pylori may be one of the etiological factors of hyperemesis gravidarum and can be added to its investigations, especially in prolonged conditions that are refractory to conventional management and cases that extend to the second trimester and non teratogenic regimens for treatment may be considered.

Keywords: Helicobacter pylori, pathogenesis, Hyperemesis gravidarum.

The protocol for this study is submitted to the Obstetrics and Gynecology unit, Faculty of medicine and to the medical ethics committee, Kufa university, Iraq.

\section{Introduction}

Hyperemesis gravidarum is severe nausea and vomiting associated with weight loss, ketonemia, ketonurea, electrolyte imbalance (hyponatraemia and hypokalaemia), metabolic hypochloraemic alkalosis and elevated liver enzymes in pregnancy ${ }^{(1)}$.It complicates $0.3-2 \%$ of all pregnancies ${ }^{(2)}$.Complications of Hyperemesis Gravidarum on the mother include; dehydration ,malnutrition, Mallory-Weiss tear of oesophagus, thromboembolic disorders,peripheral neuropathy, hypoglycaemia, acute renal failure ,Wernicke's encephalopathy due to thiamine deficiency presents with an acute confusional state $\&$ brainstem abnormalities such as ataxia, nystagmus, extraocular muscle weakness ( ifinadequately treated, this results in dementia characterized by profound disturbance of short term memory associated with tendency to confabulate called korsakoff's psychosis ${ }^{(3)}$.

The exact cause of hyperemesis gravidarum is unknown but there are some hypothesis like hormonal mechanisms, emotional factors and $\mathrm{H}$. pylori infection. The increased serum level of steroids and human chorionic gonadotrophin HCG cause change in $\mathrm{pH}$ of gastrointestinal tract, beside the pregnancy induced gastrointestinal tract dysmotility and altered humoral \&cell mediated immunity in pregnancy, all favor activation of H. pylori infection ${ }^{(4)}$.

Helicobacter pylori is one of the commonest bacterial infection world wide and accepted as the cause of chronic active gastritis.Most patients continue through life with a chronic superficial gastritis while some develop either duodenal or gastric ulcer ${ }^{(4)}$. Helicobacter pylori is a gram negative , spiral shaped, microaerophilic bacteria. The prevalence rate is higher in developing countries than developed countries ${ }^{(5)}$. Also, the prevalence of $\mathrm{H}$. pyloriis higher in overcrowded families and has a relationship with low socioeconomic status ${ }^{(6)}$.

The possible transmission route may be oral -oral, faecal -oral and iatrogenic transmission ${ }^{(7)}$. H.pylori infection is associated with enhanced gastrin release from human gastric antrum, and increasing evidence suggests a major role of cytokines in the pathogenesis of H.pylori associated gastritis and peptic ulcer disease. Also , H.pylori infection results in defective bicarbonate secretion, which normally occurs in response 
to duodenal acidification. The final result is an increased duodenal acid load in persons with $\mathrm{H}$. pylori infection (8). Simple blood (anti H. pylori antibodies), urea breath test (UBT) (that uses urea labeled with $\mathrm{Cr}$, expose the patient to a small but long lasting radioactivity, so UBT is not used in pregnancy $)^{(9)}$ and stool tests can determine if someone is infected with H. pylori. The most accurate way to diagnose is through upper GIT endoscopy of the esophagus, stomach, and duodenum ${ }^{(10)}$.

\section{Methods:}

Study objectives

To study the association of Helicobacter pylori infection in the pathogenesis of hyperemesis gravidarum (HG).

\section{Overall study design;}

This was a randomized case controlled studycarried out on 45pregnant women presenting with hyperemesis gravidarum and compare them with the same number of healthy pregnant as a control group,attending the Al-Zahra' Teaching Hospital of Gynaecology\& Obstetrics at Al- Najaf city, Iraq from March -2011 till September -2011after their written consent.

\section{Participant, recruitment and randomization}

Forty five pregnant women, their age mean was $24.96 \pm 4.719$ years, their mean gestational age was $10.64 \pm 2.047$ months ,presenting with hyperemesis gravidarum. Forty five normal pregnant women were selected as a control group with mean age $25.29 \pm 5.225$ years, their mean gestatinal ages $9.56 \pm 3.188$. A full history was taken from all cases, including history of medical disorders as peptic ulcer and history of chronic medications intake such as nonsteroidal anti-inflammatory drugs (NSAIDs), exclusion of hyperthyroidism, psychological disorders ,hepatic disorders, urinary tract infection and intracranial disorders . After general and local examinations and exclusion of any associated medical disorders, ultrasound scanning was done for both, patients group \& control group assessing fetal biometry and exclusion of any obstetric cause for hyperemesis as twin pregnancy, molar pregnancy or missed abortion.

Urine analysis for ketone bodies was done for detection of starvation ketosis. Venus blood samples were taken from patient group and control group (10ml) .After centrifugation of the Venus blood samples, 2 milliliters were sent for measurements of serum anti H.pylori antibodies ,Also,two milliliters of the centrifugedVenus blood were sent for measurement of renal functions and two milliliters were sent for measurement of liver functions.

\section{Serum H-pylori IgG antibody titer}

Serum H-pylori IgG antibody titer using commercial (ELISA) method was measured for all patient group and control group. IgG antibody titer $<3$ microgram $/ \mathrm{mL}$ was considered negative, $\operatorname{IgG}$ antibody titer 3-6 $\mu \mathrm{g} / \mathrm{mL}$ was suspicious and $\mathrm{IgG}$ titer $>6 \mu \mathrm{g} / \mathrm{mL}$ was regarded as positive.

\section{The Results}

Ages of the pregnant women in the patient group ranged from $17-35$ years (mean $24.96 \&$ SD \pm 4.719 ), their mean gestational age was $10.64 \pm 2.047$ months, twenty one ( $46.6 \%$ ) primigravidae and twenty four $(53.4 \%)$ multigravida, none of them had a history of previous peptic ulcer nor duodenal ulcer.Thirteen of the twenty four multigravidae had a history of hyperemesis in previous pregnancies.

The ages of the pregnant women in the control group ranged from 15 - 35 years (their mean $25.29 \&$ $\mathrm{SD} \pm 5.225)$, their mean gestatinal ages $9.56 \pm 3.188$, thirteen $(28.8 \%)$ were primigravidae and thirty two $(71.2$ $\%$ ) were multigravidae. ketone bodies in the urine were positive in all patient group, while ketone bodies in the urine (positive) in only five pregnants of the control group.

Among the forty five pregnant patients with hyperemesis gravidarum (patient group), there were forteen ( $31 \%$ ) patients with severe symptoms being admitted to the ward\& treated with intravenous fluids (Normal saline,Ringer's solution), antiemetics (Metoclopramide ampule of $10 \mathrm{mg}$,Prochlorperazine ampule of $12.5 \mathrm{mg}$ ), vitamine $\mathrm{B}_{6}$ (Pyridoxine $10-25 \mathrm{mg}$ thrice / day, which can be increased up to $200 \mathrm{mg} /$ day) supplement , cyclizine tablets25-50mg qd /day and corticosteroids (Betamethasone vials $4 \mathrm{mg}$ and $8 \mathrm{mg}$ ). Hospital stay ranged two -to- four days. Patients with mild and moderate symptoms ( $69 \%$ ) were treated in the emergency department by giving them intravenous fluid, antiemetics and vitamine supplements . 
The association of Helicobacter pylori in The Pathogenesis of Hyperemesis Gravidarum

Table 1: Demographic characteristics showsno significant changes regarding renal function and liver function between patient group and control group .

\begin{tabular}{|c|c|c|c|c|c|}
\hline Parametres & \multicolumn{3}{|c|}{$\begin{array}{c}\text { Pregnant patients with } \\
\text { hyperemesis } \\
\text { gravidarum } \\
(n=45)\end{array}$} & \multicolumn{2}{|c|}{$\begin{array}{l}\text { Pregnant women in } \\
\text { The control group } \\
\qquad(\mathrm{n}=45)\end{array}$} \\
\hline \multirow[t]{2}{*}{$\begin{array}{l}\text { Age mean , SD \& p-value of } \\
\text { pregnants in Both groups }\end{array}$} & mean & $\pm \mathrm{SD}$ & $\begin{array}{c}\text { p- } \\
\text { value }\end{array}$ & mean & $\pm \mathrm{SD}$ \\
\hline & 24.96 & \pm 4.79 & 0.752 & 25.29 & \pm 5.225 \\
\hline $\begin{array}{l}\text { The mean,SD\& p- value of } \\
\text { the gestational age( whs) }\end{array}$ & 10.69 & \pm 2.047 & 0.057 & 9.56 & \pm 3.188 \\
\hline Primigravidae & \multicolumn{3}{|c|}{21} & \multicolumn{2}{|c|}{13} \\
\hline Multigravidae & \multicolumn{3}{|c|}{24} & \multicolumn{2}{|c|}{32} \\
\hline $\begin{array}{l}\text { history of prevous } \\
\text { pregnancy with } \\
\text { Lr: }\end{array}$ & \multicolumn{3}{|c|}{13} & \multicolumn{2}{|c|}{10} \\
\hline $\begin{array}{l}\text { No history of prevous } \\
\text { pregnancy with HG }\end{array}$ & \multicolumn{3}{|c|}{11} & \multicolumn{2}{|c|}{22} \\
\hline $\begin{array}{l}\text { Number of patients } \\
\text { Admitted to the ward }\end{array}$ & \multicolumn{3}{|c|}{14} & \multicolumn{2}{|c|}{ zero } \\
\hline
\end{tabular}

Table 2: Statistcal analysis of the data of liver and renal functions of both patient and control groups .

\begin{tabular}{|l|l|l|l|l|l|l|l|}
\hline & \multicolumn{4}{|c|}{ Patient Group (n=45) } & \multicolumn{3}{c|}{ Control Group (n=45) } \\
\cline { 2 - 8 } & $\mathrm{n}=$ & mean & $\pm \mathrm{SD}$ & $\mathrm{p}$-value & $\mathrm{n}=$ & mean & $\pm \mathrm{SD}$ \\
\hline Blood Urea & 45 & 21.78 & \pm 5.27 & 0.214 & 45 & 20.47 & \pm 4.58 \\
\hline Serum Creatinin & 45 & 0.287 & \pm 0.174 & 0.253 & 45 & 0.250 & \pm 0.121 \\
\hline SGOT & 45 & 22.98 & \pm 7.32 & 0.533 & 45 & 21.84 & \pm 5.70 \\
\hline SGPT & 45 & 18.36 & \pm 6.53 & 0.310 & 45 & 17.60 & \pm 4.92 \\
\hline Alk-Phosphitas & 45 & 31.93 & \pm 14.71 & 0.621 & 45 & 30.53 & \pm 11.87 \\
\hline
\end{tabular}


Table -3-Percentages of H.pylori seroposetive among the patients group $\&$ the control group.

\begin{tabular}{|c|c|c|c|c|c|c|c|c|c|}
\hline Parameters & \multicolumn{5}{|c|}{$\begin{array}{l}\text { The Patient Group } \\
\qquad(\mathrm{n}=45)\end{array}$} & \multicolumn{4}{|c|}{$\begin{array}{l}\text { The Control Group } \\
\qquad(\mathrm{n}=45)\end{array}$} \\
\hline $\begin{array}{l}\text { H.pylori } \\
\text { *Parameter } \\
\text { s }\end{array}$ & $\begin{array}{c}N=4 \\
5\end{array}$ & $\%$ & $\begin{array}{c}\text { Mea } \\
\mathbf{n}\end{array}$ & $\begin{array}{c}\text { SD } \\
\pm\end{array}$ & $\begin{array}{c}\text { p- } \\
\text { valu } \\
\mathrm{e}\end{array}$ & $\begin{array}{c}N=4 \\
5\end{array}$ & $\%$ & $\begin{array}{c}\text { Mea } \\
\text { n }\end{array}$ & $\mathrm{SD} \pm$ \\
\hline $\begin{array}{c}\text { *Seroposetiv } \\
\mathrm{e}\end{array}$ & 38 & $\begin{array}{c}84 . \\
4\end{array}$ & $\begin{array}{c}31.7 \\
2\end{array}$ & $\begin{array}{c}24 . \\
6\end{array}$ & 0.000 & 21 & 46.7 & 13.7 & 18.6 \\
\hline $\begin{array}{c}\text { * Seronegativ } \\
\mathrm{e}\end{array}$ & 7 & $\begin{array}{c}15 \\
6\end{array}$ & & 8 & & 24 & 53.3 & & \\
\hline
\end{tabular}

H.pylori serum antibody test was positive in 38 out of $45(84.44 \%)$ patients with hyperemesis gravidarum (their age mean was $31.72, \mathrm{SD} \pm 5.6 \& \mathrm{p}$-value $=0.000$ ) , while H.pylori serum antibody test was positive in only 21 out of $45(46.7 \%)$ in the control group pregnant women, (their age mean was $20.7 \&$ SD $\pm 4.6)$ as in Table -3-above.

\section{Discussion:}

Hyperemesis gravidarum (HG) is a common problem for an obstetrician ${ }^{(11)}$.A small percentage, 1$2 \%$, of pregnant women have a more severe course, being HG.

Although several theories have been proposed, the exact cause remains unclear. Several recent researches have implicated the Helicobacter pylori as one possible cause ${ }^{(12)}$.Helicobacter Pylori causes a noninvasive infection of the gastric epithelium and the mucous layer that coats this epithelium. It can cause duodenal ulcer, gastric ulcer, chronic gastritis, gastric adenocarcinoma, mucosa associated lymphoid tissue lymphoma and a few other rare upper gastrointestinal disorders ${ }^{(13)}$. It is reported that gastric mucosa that is infected by Helicobacter pylori almost always shows a combination of inflammation and epithelial changes. The classical feature caused by this organism is chronic active gastritis. The infiltrate generally consists of monocytes and neutrophils. The degree of inflammation varies in severity from a minimal inflammatory infiltrate in the lamina propria with preserved architecture to severe gastritis with dense inflammation. In very severe cases intraepithelial neutrophils can be detected in both, the surface epithelium and the gastric pits as microabscesses ${ }^{(14)}$.

In our study, incidence of $\mathrm{H}$ pylori was significantly higher in pregnant patients with hyperemesis gravidarum $84.4 \%$ than control group $46.7 \%$. This goes with Ehab et al.,2010, who found that H. pylori serum antibody test was positive in 54 out of 62 hyperemesis cases $(87 \%)$ while in the control were 20 out of $62(32 \%)^{(15)}$.

Also our study agrees with the study of T. Kazerooniet al., who found that Serologically positive Helicobacter pylori infection was detected in 44 out of 54 patients with hyperemesis gravidarum $(81.5 \%)$ whereas 29 out of 53 asymptomatic gravidas $(54.7 \%)$ had positive antibody titers for Helicobacter pylori. The ratio of Helicobacter pyloriseropositivity in pregnant women with hyperemesis gravidarum was significantly higher than asymptomatic pregnant women $(P<0.01)$. The mean $( \pm$ S.D. $)$ of the IgG titer was $69.7( \pm 77.5)$ in the hyperemesis gravidarum group and $34.5( \pm 47.8)$ in the control group $(P<0.01)$. theyconcluded that there is a significant association between Helicobacter pylori infection and hyperemesis gravidarum in our hyperemetic pregnant patients ${ }^{(16)}$. Other study done by Ahmet Erdem, Murat Arslan, et al, they found that The prevalence of H. pylori infection was $85.1 \%$ (40 of 47) and $64.1 \%$ (25 of 39) in patients with HG and controls, respectively $\left(p<0.05, \chi^{2}\right.$ test). Mean values of $H$. pylori $\operatorname{IgG}$ ( \pm standard deviation) were significantly higher in patients with HG than in controls $(22.66 \mathrm{aIU} / \mathrm{mL} \pm 22.34 \text { vs. } 11.54 \mathrm{aIU} / \mathrm{mL} \pm 13.89, p<0.01 \text {, Student's } t \text {-test })^{(17)}$.

The fourteen patients with severe hyperemesis gravidarum who were admitted to the ward showed marked improvement with declining of number of vomiting attacks which became from 0-2 attacks per day and subsiding of epigastric pain . No one of our pregnant patients with hyperemesis gravidarum who were admitted 
to the ward needed upper gastrointestinal tract endoscopic examination. NeitherMetronidazole nor proton pump inhibiters were used in this study.More studies on the safety of proton pump inhibitors during pregnancy ought to be done because proton pump inhibitors can give better results in these cases

\section{Conclusion and recommendation:}

1) Helicobacter pylori can be considered as one of the causes of hyperemesis gravidarum.

2) Screening for Helicobacter pylori canbe added to the investigations of pregnant women with hyperemesis gravidarum, especially in prolonged conditions that are refractory to conventional management and cases that extend to the second trimester .

3) Non teratogenic regimens for treatment of Helicobacter pylori may be considered in intractable cases of hyperemesis gravidarum, this needs further studies.

4) Further studies may be needed to confirm that early treatment of hyperemesis gravidarum may decrease the rate of abortion and congenital anomalies of fetus,

\section{References}

[1]. Cunningham G, Gant NF, Kenneth JL,Gilstrap LC, Hauth JC, Wenstrom KD. William's obsteyrics $21^{\text {th }}$ ed. McGraw-Hill company; 2001.p. 1275-1276.

[2]. M.F.G.Verberg, D.J.Gillott1, N.Al-Fardan and J.G.Grudzinskas. Hyperemesis gravidarum, a literature review .Human Reproduction Update, 2005, Vol.11, No.5 pp. 527-539.

[3]. Holmgren C, Aagaard-Tillery KM, Silver RM, et al. Hyperemesis in pregnancy: an evaluation of treatment strategies with maternal and neonatal outcomes. Am J Obstet Gynecol. Jan 2008;198(1):56.e1-4. [Medline].

[4]. Eliakim R, Abulafia O, Sherer DM. Hyperemesis gravidarum: A current review. Am J Perinatol. 2000;17(4):207-217.

[5]. Maggie C,AshalathaS.Clinical Cases Uncovered in Obstetrics and Gynaecology. $1^{\text {st }}$ ed.SussexUK; Wiley-BlackWell :2009 .

[6]. Werntoft E, Dykes AK. Effect of acupressure on nausea and vomiting during pregnancy: A randomized, placebo-controlled, pilot study. J Reprod Med. 2001;46(9):835-839.

[7]. Fausi L. Kaspar, Hauser Longo. principles of Harrison's medicine.15th edition , McGraw Hill, 2001; 960-964

[8]. Jamal A, Pooransari P, Andansari R .Relationship between helicobacter pylori seropositivity and hyperemesis gravidarum.actamedica iranica.2004;42(5).

[9]. Chey WD, Wong BC. American College of Gastroenterology guideline on the management of Helicobacter pylori infection.Am $J$ Gastroenterol . 2007;102(8):1808-1825.

[10]. Panesar NS, Li CY and Rogers MS .).Are thyroid hormones or HCG responsible for hyperemesis gravidarum? A matched paired study in pregnant Chinese women. ActaObstetGynecol Scand. 2001; (80):519-524.

[11]. Tan PC, Tan NC, Omar SZ.Effect of high levels of human chorionic gonadotropin and estradiol on the severity of hyperemesis gravidarum .Clin Chem Lab Med. 2009;47(2):165-71.

[12]. Dotun A Ogunyemi, MD; Chief Editor: David Chelmow, MD.Hyperemesis Gravidarum.Medscape . Updated: Jun 19, 2009

[13]. Quinla JD, Hill DA. Nausea and vomiting of pregnancy.American Family Physician.2003;68(1):121-128.

[14]. Ehab H. N, MD, Ghada M. M, MD. Helicobacter pylori and Hyperemesis Gravidarum . Nature and Science $.2010 ; 8(8)$.

[15]. T. Kazerooni, M. Taallom, A. Ghaderi. Helicobacter Pylori Seropositivity among Patients with Hyperemesis gravidarum, IJMS, June 2002 Vol 27, No 2, 67.

[16]. Ahmet Erdem, Murat Arslan, Mehmet Erdem, Gizem Yildirim, Özdemir Himmetoğlu. Detection of Helicobacter pylori Seropositivity in Hyperemesis Gravidarum and Correlation with Symptoms.Amer J Perinatol 2002; 19(2): 087-092 